\title{
GMR
}

\section{Identification of lipopeptides produced by Bacillus subtilis Czk1 isolated from the aerial roots of rubber trees}

\author{
C.P. He ${ }^{1,3 *}$, L.Y. Fan ${ }^{2 *}$, W.H. Wu ${ }^{1 *}$, Y.Q. Liang ${ }^{1}$, R. Li ${ }^{1}$, W. Tang ${ }^{2}$, \\ X.L. Zheng ${ }^{1}$, Y.N. Xiao ${ }^{3}$, Z.X. Liu ${ }^{4}$ and F.C. Zheng ${ }^{2}$ \\ ${ }^{1}$ Hainan Key Laboratory for Monitoring and Control of Tropical Agricultural Pests, \\ Environment and Plant Protection Institute, \\ Chinese Academy of Tropical Agricultural Sciences, Haikou, Hainan, China \\ ${ }^{2}$ College of Environment and Plant Protection, Hainan University, Haikou, \\ Hainan, China \\ ${ }^{3}$ College of Plant Science and Technology of Huazhong Agricultural University, \\ Wuhan, Hubei, China \\ ${ }^{4}$ Institute of Tropical Bioscience and Biotechnology, \\ Chinese Academy of Tropical Agricultural Sciences, Haikou, Hainan, China \\ *These authors contributed equally to this study. \\ Corresponding authors: Y.N. Xiao / Z.X. Liu \\ E-mail: xiaoyannong@mail.hzau.edu.cn / liuzhixin@itbb.org.cn
}

Genet. Mol. Res. 16 (1): gmr16018710

Received April 14, 2016

Accepted February 7, 2017

Published February 23, 2017

DOI http://dx.doi.org/10.4238/gmr16018710

Copyright (C) 2017 The Authors. This is an open-access article distributed under the terms of the Creative Commons Attribution ShareAlike (CC BY-SA) 4.0 License.

ABSTRACT. We obtained a strain of Bacillus subtilis, which we
named Czk1, from the aerial roots of rubber trees. This bacterial isolate
exhibits strong antagonistic activity against Ganoderma pseudoferreum,
Phellinus noxius, Helicobasidium compactum, Rigidoporus lignosus,
Sphaerostilbe repens, and Colletotrichum gloeosporioides. Our earlier
research has shown that the antagonistic activity of a fermentation
supernatant Czk1 isolate produces a complex mixture of lipopeptides.
In this study, we used methanol to extract crude lipopeptides, purified
them using a Sephadex G-25 column, cloned the lipopeptide genes, and

Genetics and Molecular Research 16 (1): gmr16018710 
analyzed purified fractions by matrix-assisted laser desorption ionizationtime of flight mass spectrometry (MALDI-TOF-MS) to identify the lipopeptides from $B$. subtilis strain Czk1. The cloned lipopeptide genes included those that encode the enzymes lpa, ituD, sfp, and fenB. The crude lipopeptides were purified and found in five fractions. Further analysis revealed that five fractions of the purified composition contained members of the surfactin, iturin, fengycin, and bacillomycin families of antibiotics. This suggests that these lipopeptides from strain Czk1 have potential as plant disease biocontrol agents.

Key words: Bacillus subtilis; Antifungal activity; Lipopeptide; Colletotrichum gloeosporioides; MALDI-TOF-MS

\section{INTRODUCTION}

The rubber tree (Hevea brasiliensis) is a wild tropical angiosperm that belongs to the Euphorbiaceae family (Dornelas and Rodriguez, 2005). It is considered an important perennial crop species because it is the source of natural rubber. However, rubber trees are often affected by various diseases, including root diseases (Oghenekaro et al., 2014), Colletotrichum leaf disease (CLD) (Jayasinghe et al., 1997; Cai et al., 2013), powdery mildew (Mitra and Mehta, 1938; Limkaisang et al., 2005), Corynespora leaf fall (CLF) (Chee, 1990), etc. (Jayasinghe et al., 1997; Cai et al., 2013; Oghenekaro et al., 2014). CLD is one of the major causes of the decline in rubber yields in Asia (Thambugala and Deshappriya, 2009). Colletotrichum gloeosporioides causes the CLD that affects rubber (Cai et al., 2013; Yong et al., 2014). This pathogen can attack any of the green parts of the plant, including young leaves, shoots, and pods. In its most severe form, CLD causes secondary leaf fall in rubber trees; as a consequence, huge economic losses have been recorded (Wastie, 1967). In China, root diseases and CLD are a severe problem, and are considered limiting factors that seriously affect rubber production. For example, huge yield losses attributed to CLD have been observed in Hainan, Guangdong, and Yunnan provinces when weather conditions are favorable for disease outbreaks (Cai et al., 2009). CLD is usually controlled by chemical fungicides such as benomyl, maneb, chlorothalonil, and mancozeb (Mahoney and Tattar, 1980). However, the increased use of chemical fungicides has led to the development of fungicide-resistant fungal strains (Howarth, 1991; Peres et al., 2004). Therefore, biocontrol agents may be a more efficient and environmentally friendly alternative to fungicides for the control of rubber diseases.

Bacillus spp are often regarded as optimum candidates for the control of plant diseases because they can secrete antifungal compounds (Pathak and Keharia, 2014; Yang et al., 2015). The majority of Bacillus strains can produce antimicrobial compounds. For instance, Bacillus spp can generate antimicrobial peptides including various classes of bacteriocins (Klaenhammer, 1993), and antimicrobial surface-active biosurfactants such as lipopeptides, glycopeptides, and non-ribosomally synthesized cyclic peptides (Mukherjee et al., 2006; Rodrigues et al., 2006). Lipopeptides comprise peptides with 7-10 amino acids cyclized via a lactone ring to $\beta$-hydroxy fatty acids of varying chain length (Baindara et al., 2013). These lipopeptides mainly differ in their amino acid sequences and fatty acid branches; they are produced by various Bacillus spp and can be further divided into three families: iturin (Delcambe et al., 1977); fengycin (Vanittanakom et al., 1986); and surfactin (Arima et al., 1968). The BAA

Genetics and Molecular Research 16 (1): gmr16018710 
lengths of iturin members vary from 14 to 17 carbon atoms (Pathak and Keharia, 2014). Iturins are also classified on the basis of the variation of amino acids in their corresponding peptide moieties: iturin $\mathrm{A}$, iturin $\mathrm{C}$, iturin $\mathrm{D}$, iturin $\mathrm{E}$, bacillomycin $\mathrm{D}$, bacillomycin $\mathrm{F}$, bacillomycin L, bacillomycin Lc, and mycosubtilin (Winkelmann et al., 1983; Gong et al., 2006; Romero et al., 2007; Pecci et al., 2010). Iturin A is the most promising antifungal lipopeptide because it is secreted by most Bacillus strains and is characterized by strong and broad-spectrum antifungal activity (Romero et al., 2007; Pecci et al., 2010). Surfactin contains a $\beta$-hydroxy fatty acid with 13 to 15 carbon atoms (Koumoutsi et al., 2004). The members of the fengycin family comprise $\beta$-hydroxy fatty acids with 13 to 15 carbon atoms (Koumoutsi et al., 2004). They have unusual properties such as the presence of ornithine in the peptide portion and antifungal activity, and they are more specific to filamentous fungi than to other fungal types (Steller et al., 1999; Vanittanakom et al., 1986). The lipopeptides belonging to the surfactin family are $\beta$-hydroxy heptacyclic depsipeptides with Ala, Val, Leu, or Ile variations at positions 2,4 , and 7 in the cyclic depsipeptide moieties, and $\mathrm{C} 13$ to $\mathrm{C} 16$ variations in the $\beta$-hydroxy fatty acid chains (Peypoux et al., 1994; Kowall et al., 1998; Hue et al., 2001). Different Bacillus strains also exhibit diversity in the production of cyclic lipopeptides; for example, most Bacillus strains produce lipopeptides belonging to only one family, whereas a few strains co-produce lipopeptides belonging to two or three families (Vater et al., 2002; Nagórska et al., 2007; Romero et al., 2007; Pecci et al., 2010).

Previously, we have isolated Bacillus subtilis Czk1 from the aerial roots of rubber trees; B. subtilis Czk1 exhibits in vitro antifungal activity against several plant pathogens: Ganoderma pseudoferreum, Phellinus noxius, Helicobasidium compactum, Rigidoporus lignosus, Sphaerostilbe repens, and Colletotrichum gloeosporioides (Zhao et al., 2011). We found that the antifungal activity of B. subtilis Czk1 supernatants is tolerant of high temperatures and is not sensitive to ultraviolet radiation or the action of protease $\mathrm{K}$ (Fan et al., 2013). Other researchers have reported that the antifungal activity of $B$. subtilis Czk1 supernatants is stable at high temperatures $\left(40^{\circ}-130^{\circ} \mathrm{C}\right)$ and is resistant to enzymatic degradation (proteinase $\mathrm{K})$; these characteristics are typically associated with the lipopeptide antibiotics produced by Bacillus spp (Stein, 2005; Geetha et al., 2010). In the current study, we aimed to determine the antibiotic category of $B$. subtilis Czk1 by detecting the specific markers of several enzymes involved in antimicrobial peptide synthesis. Those enzymes were: ituD (ituD synthetase D); lpa (lipopeptide antibiotic iturin A); sfp (4'-phosphopantetheinyl transferase for surfactin synthesis); and fenB (fengycin synthetase B for fengycin B synthesis). We also analyzed the obtained lipopeptide fractions using a Sephadex G-25 column and matrix-assisted laser desorption ionization-time of flight mass spectrometry (MALDI-TOF-MS) to identify the putative compounds responsible for the antifungal activity of the supernatants. This is the first report of a $B$. subtilis strain from Hevea brasiliensis co-producing so many variants of fengycins, surfactins, and iturins.

\section{MATERIAL AND METHODS}

\section{Bacterial strain and design of primers}

B. subtilis Czk1 was isolated from the aerial roots of a rubber tree (He et al., 2012). The isolates were checked for purity and preserved at $-70^{\circ} \mathrm{C}$ for future studies. The indicator strain used in this study was $C$. gloeosporioides isolate RC178 obtained from a rubber tree

Genetics and Molecular Research 16 (1): gmr16018710 
stored in the laboratory of the Environment and Plant Protection Institute (Chinese Academy of Tropical Agricultural Sciences, Haikou, China). The specific primers for the target antifungal genes for polymerase chain reaction (PCR) assays were designed on the basis of the nucleotide sequences of $i t u D$ (the gene that encodes ituD synthetase $\mathrm{D}$ ), lpal4 (the gene that encodes the lipopeptide antibiotic iturin A), sfp (the gene that encodes 4'-phosphopantetheinyl transferase for surfactin synthesis), and fenB (the gene that encodes fengycin synthetase B for fengycin B synthesis). The primers were synthesized under salt-free conditions. The nucleotide sequences of the PCR primers used in this study are listed in Table 1.

\begin{tabular}{|c|c|c|c|c|}
\hline Primer & Sequence $\left(5^{\prime}-3^{\prime}\right)$ & Target gene & Gene ID & Product length (bp) \\
\hline$S f p \mathrm{~F} / \mathrm{R}$ & $\begin{array}{l}\text { F: ATGAAGATTTACGGAATTTA } \\
\text { R: TTATAAAAGCTCTTCGTACG }\end{array}$ & Sfp 4'-Phosphopanteinyl transferase & EU882341.1 & 675 \\
\hline $\mathrm{FenBF} / \mathrm{R}$ & $\begin{array}{l}\text { F: CTATAGTTTGTTGACGGCTC } \\
\text { R: CAGCACTGGTTCTTGTCGCA }\end{array}$ & fen B Fengycin synthetase B & JN086144 & 1401 \\
\hline$l p a-14 \mathrm{~F} / \mathrm{R}$ & $\begin{array}{l}\text { F: ATGAAAATTTACGGAGTATA } \\
\text { R: TTATAACAGCTCTTCATACG }\end{array}$ & lpa-14 lpa-14 gene encoding the lipopeptide antibiotic iturin A & D21876.1 & 675 \\
\hline$i t u D \mathrm{~F} / \mathrm{R}$ & $\begin{array}{l}\text { F: ATGAACAATCTTGCCTTTTT } \\
\text { R: TTATTTTAAAATCCGCAATT }\end{array}$ & $i t u D$ synthetase $\mathrm{D}$ & KF381340 & 1203 \\
\hline
\end{tabular}

\section{PCR amplification and sequencing}

The total DNA of B. subtilis Czk1 was extracted using a BioMiGA kit (San Diego, USA) in accordance with the manufacturer instructions. PCR amplifications were performed in a $20 \mu \mathrm{L}$ reaction mixture containing $20 \mathrm{ng}$ template DNA, 2X EconoTaq PCR SuperMix (10 $\mu \mathrm{L}$; Beijing TransGen Biotech Co., Ltd.), and $0.5 \mu \mathrm{L}$ each primer $(10 \mu \mathrm{mol} / \mathrm{L})$; ddH2O was added to obtain the final volume. Templates were amplified in an ABI 9600 thermal cycler under the following cycling conditions: one interval of $94^{\circ} \mathrm{C}$ for $3 \mathrm{~min} ; 35$ cycles of $94^{\circ} \mathrm{C}$ for $30 \mathrm{~s}, 50^{\circ}-60^{\circ} \mathrm{C}$ for $30 \mathrm{~s}$, and $72^{\circ} \mathrm{C}$ for $1-2 \mathrm{~min}$; and one cycle of $72^{\circ} \mathrm{C}$ for $5 \mathrm{~min}$. After the amplified templates had been confirmed by running the samples on $1.0 \%$ agarose gel, each PCR amplicon was purified by PCR using version 2.0 of the TaKaRa fragment DNA purification kit (TaKaRa Biotechnology, Dalian, China) and cloned into a pGEM ${ }^{\circledR}$-T Easy Vector (Promega, Madison, WI, USA) in accordance with the manufacturer instructions. Each amplicon was transformed into Escherichia coli DH5á and subsequently sequenced by Sangon Biotech (Shanghai, China) using the primers M13F (ACTGGCCGTCGTTTTAC) and M13R (GTCATAGCTGTTTCCTG). Three colonies were recovered from each ligation reaction and sequenced separately. The sequences were BLASTed using the National Center for Biotechnology Information (NCBI) blastx program (http://blast. ncbi.nlm.nih.gov/Blast.cgi).

\section{Lipopeptide production and extraction}

A colony of $B$. subtilis Czk1 was inoculated into Luria broth $(50 \mathrm{~mL})$ in a $250-\mathrm{mL}$ Erlenmeyer flask, and incubated at $28^{\circ} \mathrm{C}$ and $180 \mathrm{rpm}$ for $24 \mathrm{~h}$. The 24-h-old inoculum was then used to seed $250 \mathrm{~mL}$ yeast extract peptone dextrose medium (YPD medium; composition in $\mathrm{g} / \mathrm{L}: 1 \%$ yeast extract, $2 \%$ peptone, $2 \%$ glucose) in a $1000-\mathrm{mL}$ flask to an initial $\mathrm{OD}_{600}$ (optical density measured at a wavelength of $600 \mathrm{~nm}$ ) of approximately 0.05 . The inoculum was then incubated at $28^{\circ} \mathrm{C}$ and $180 \mathrm{rpm}$ for $72 \mathrm{~h}$.

The 72-h-old fermentation broth of B. subtilis $\mathrm{Czk} 1$ was centrifuged at approximately

Genetics and Molecular Research 16 (1): gmr16018710 
$10,000 \mathrm{rpm}$ and $4^{\circ} \mathrm{C}$ for $10 \mathrm{~min}$. The supernatant was collected, and its $\mathrm{pH}$ was reduced to 4 using concentrated $\mathrm{HCl}$; it was then incubated at $4^{\circ} \mathrm{C}$ overnight to precipitate the lipopeptides. The acid precipitates were recovered by centrifugation at approximately $10,000 \mathrm{rpm}$ and $4^{\circ} \mathrm{C}$ for $10 \mathrm{~min}$, and freeze-dried; the obtained pellet was solubilized in anhydrous methanol (Pathak et al., 2012) and extracted twice. The methanolic lipopeptide extract was further concentrated using a vacuum evaporator (Buchi, Switzerland).

\section{Chromatographic purification and in situ acid hydrolysis in Sephadex G-25}

The yellowish-brown extract was dissolved in a small quantity of chloroform/methyl alcohol (1:1) and filtered using a $0.45-\mathrm{mm}$ membrane; the dissolved extract was then added to a Sephadex G-25 chromatographic column $(1 \times 60 \mathrm{~cm}$; Shanghai Biological Engineering Co., Ltd., China). Chloroform/methyl alcohol (1:1) was used as the mobile phase to collect each constituent at a flow rate of $6 \mathrm{drops} / \mathrm{min}$ to obtain $20 \mathrm{~mL}$ in each tube. Each constituent was merged with ninhydrin/methyl alcohol as a color developing agent and chloroform/ methyl alcohol/water (65:25:4) as a developing solvent. One thin layer chromatography (TLC; Qingdao Marine Chemical, China) plate was heated to develop color with $0.5 \%$ ninhydrin/ethyl alcohol, and the other TLC plate was placed in a development cylinder with $1 \mathrm{~mL}$ concentrated hydrochloric acid for $2 \mathrm{~h}$ of in situ acid hydrolysis in an airtight and high-temperature $\left(110^{\circ} \mathrm{C}\right)$ environment. This TLC plate was removed from the cylinder and transferred to a fume cupboard to complete the volatilization of hydrochloric acid before $0.5 \%$ ninhydrin/ethyl alcohol was used for color development. The colorations of the two plates were observed and the same constituent was merged after the in situ acid hydrolysis was complete.

Each active constituent was detected using the cylinder plate method, with $C$. gloeosporioides growing on a rubber tree used as the indicator fungus; the constituents were selected via a spore germination experiment and further analyzed.

In the spore germination experiment, the conidium form of $C$. gloeosporioides was washed off the plate with $2 \%$ glucose/water solution; under a $10 \times 10$ microscope, the spore count was adjusted to approximately 100 conidia in the visual field. Next, $20-\mu \mathrm{L}$ samples of each composition were coated evenly on slides. Another $20 \mu \mathrm{L}$ of the spore suspension was coated on the sensitive layer once the first layer had formed following organic solvent evaporation. Methyl alcohol/chloroform (1:1) and water were used for contrast, and each treatment was repeated three times. When the germination rate in the control group reached $>80 \%$ (approximately $10-12$ h), the germination of the spores in the differently treated groups was observed. Three random visual fields were observed (repeated three times) for each treatment; the number of germinated spores and the total number of spores were recorded (spore germination was defined as the point at which the length of the germ tube exceeded the short radius).

\section{MALDI-TOF-MS analysis}

All the active lipopeptide fractions obtained $(20-\mu \mathrm{L}$ samples) were analyzed by MALDI-TOF-MS detection at Nanjing Agricultural University.

\section{RESULTS}

We used the specific PCR primers to detect antimicrobial biosynthetic genes in $B$.

Genetics and Molecular Research 16 (1): gmr16018710 
subtilis Czk1. We designed four primer pairs to detect antifungal genes. The expected DNA bands were detected following amplification with the specific primers for the DNA extracted from B. subtilis Czk1 (Figure 1). The specific $s f p \mathrm{~F} / \mathrm{R}$, ituDF/R, lpa $14 \mathrm{~F} / \mathrm{R}$, and $f e n B \mathrm{~F} / \mathrm{R}$ primers successfully amplified the DNA band from B. subtilis Czk1 and produced 675, 1203, 675, and $1401 \mathrm{bp}$ bands in the lanes, respectively (Figure 1).

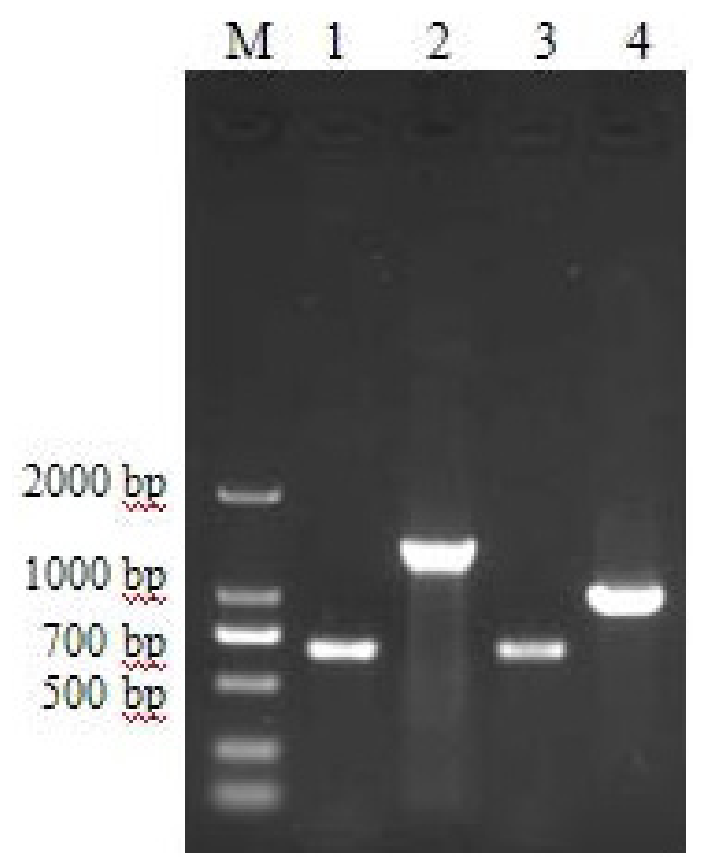

Figure 1. Molecular detection of the genes corresponding to antimicrobial substances. Lane M: DNA marker; lanes 1-4: sfp, fenB, lpa14, and ituD.

\section{Multiple gene nucleotide alignments}

To further confirm the genes corresponding to the antimicrobial substances, the genespecific bands were recovered and cloned for sequencing. The sequence analysis revealed $98 \%$ homology between the $B$. subtilis Czk $1 s f p$ gene nucleotide sequence (675 bp) and the $s f p$ gene of Bacillus amyloliquefaciens LX-11 (JN086145.1). Similarly, we found 98\% homology between the $B$. subtilis Czk1 sfp gene nucleotide sequence and the $s f p$ genes related to surfactin synthesis in B. amyloliquefaciens FZB42 (CP000560.1). The homology between the fengycin synthesis-related fenB sequence (1401 bp) amplified from B. subtilis Czk1 and that from the B. amyloliquefaciens 96-79 (EU882342.1) bacterial strain was 99\%. The fengycin synthesisrelated $f e n B$ sequence was $97 \%$ homologous to the genes related to the synthesis of the $B$. amyloliquefaciens LX-11 (JN086144.1) fengycin enzyme. Furthermore, lpa14 (675 bp), which is related to iturin synthesis, was $98 \%$ identical to the gene controlling the synthesis of iturin A (lpa14) in B. subtilis RP24 (EU797520.1). The ituD genes (1203 bp) were 99\% identical to $B$. subtilis COGB29 (HQ7116.1) ituD. These findings indicate that the genes related to the three major metabolites (surfactin, iturin, and fengycin) exist in the genome of B. subtilis Czk1.

Genetics and Molecular Research 16 (1): gmr16018710 


\section{Purification of lipopeptides and detection of antifungal activity}

The polygene test results initially confirmed the presence of genes related to lipopeptide synthesis in Bacillus spp. We carried out an in situ acid hydrolysis experiment to identify lipopeptides (Figure 2A). The two TLC plates were compared, and the results revealed that free amino acid residues were released from the closed structure after acid hydrolysis (Figure 2B), as indicated by numerous orange-yellow or salmon dots on the plate dyed by in situ acid hydrolysis. Therefore, these residues were identified as lipopeptide antibiotics (Hou et al., 2006). Seven fractions were found after the same fraction was merged following in situ acid hydrolysis.
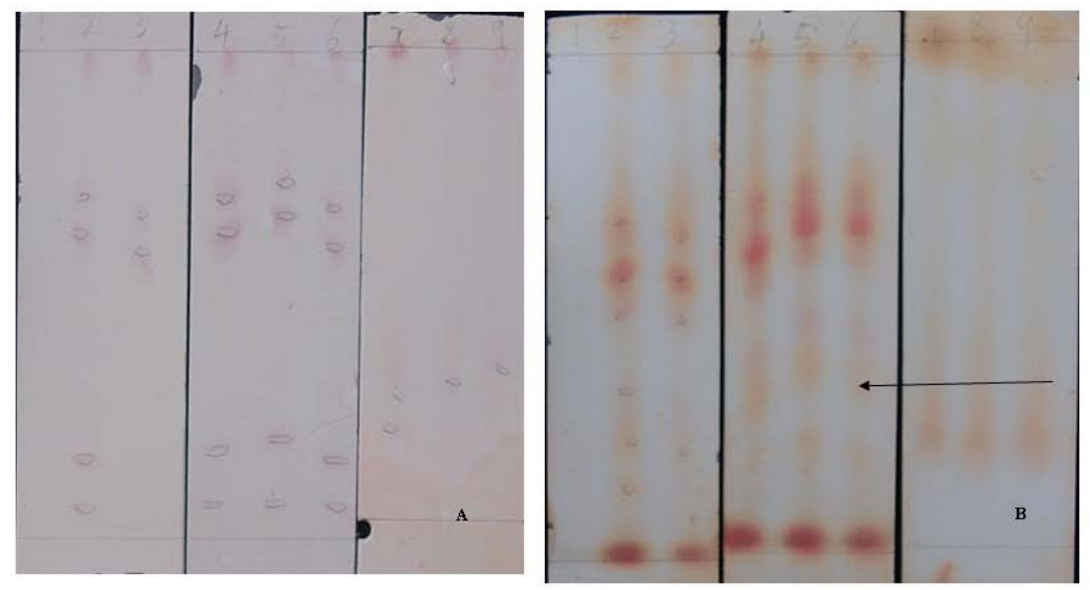

Figure 2. A. Direct dyeing with ninhydrin/ethanol; and B. ninhydrin/ethanol after acidolysis.

The activity of $C$. gloeosporioides was detected using all fractions via the cylinder plate method. Only five fractions elicited an inhibitory effect on RC178. Thus, the five fractions were renamed F1, F2, F3, F4, and F5 (Figure 3). Among these fractions, that fractions F3 and F4 exhibiting a strong antimicrobial activity (Figure 3). By contrast, fractions F1, F2, and F5 yielded weak antimicrobial activity on RC178 without an evident inhibition zone (Figure 3). However, the spore germination experiment revealed that the spore germination of RC178 was inhibited by the five fractions (Figure 4). When the germination rate in the control group was $>80 \%$ (the $1: 1$ ratio of methyl alcohol/chloroform did not affect germination) (Figure $4 \mathrm{~A}-\mathrm{C}$ ), the single spore in the six-fold diluent of fraction F5 germinated with a germination rate of $<5 \%$ (Figure $4 \mathrm{~L}$ ). The two- or four-fold diluent of fraction F5 and the four- or sixfold diluent of fraction F1 could stop germination in a short period, and the spore did not exhibit malformation or expansion (Figure 4E-F, J-K). Fraction F3 elicited the largest influence on spore germination: its two-, four-, and six-fold diluent could stop the entire spore differentiation by inducing the malformation and expansion of the spore top and by changing the permeability of the cell wall (Figure 4G-I). The two-fold diluents of fraction F1, F2, and F4 could also inhibit the spore germination, and the single spore underwent top expansion or malformation (Figure 4D). However, the four- and six-fold diluents of the three fractions did not affect the spores, and the spores were not germinated.

Genetics and Molecular Research 16 (1): gmr16018710 


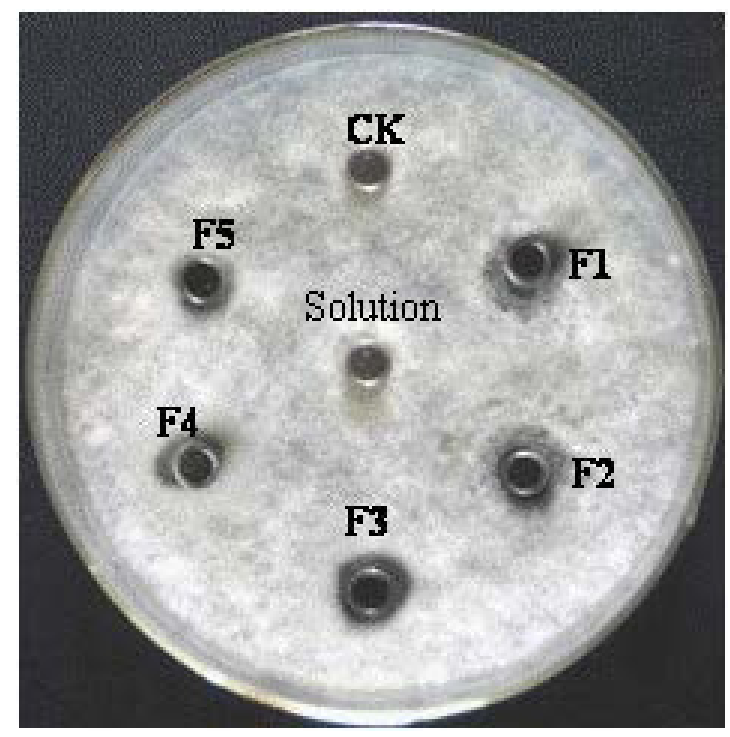

Figure 3. Effect of the five components on Colletotrichum gloeosporioides RC178 from a rubber tree.
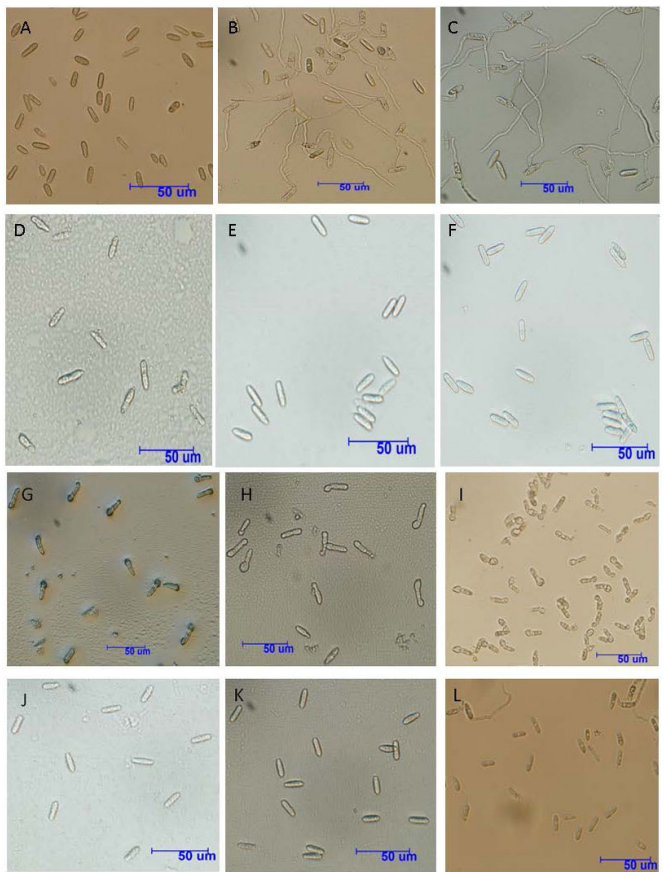

Figure 4. Influence of different diluent concentrations on the conidium germination of Colletotrichum gloeosporioides from a rubber tree. A. normal spores; B. no-treatment control; C. methyl alcohol/chloroform (1:1); D. two-fold dilution of F1; E. four-fold dilution of F1; F. six-fold dilution of F1; G. two-fold dilution of F3; H. four-fold dilution of F3; I. six-fold dilution of F3; J. two-fold dilution of F5; K. four-fold dilution of F5; and L. six-fold dilution of F5.

Genetics and Molecular Research 16 (1): gmr16018710 


\section{MALDI-TOF-MS analysis}

The MALDI-TOF-MS analysis of the Sephadex G-25-purified fractions of crude antifungal extract obtained from the liquid culture-grown supernatant of B. subtilis Czk1 revealed the presence of compounds with molecular mass to charge number ratio $(\mathrm{m} / \mathrm{z})$ ranges of 994-1065, 1028-1109, and 1421-1566, which we attributed to surfactins, iturins, and fengycins, respectively (Kowall et al., 1998; Vater et al., 2002; Williams and Brodbelt, 2004; Gong et al., 2006; Romero et al., 2007; Pathak et al., 2012). Fractions 1-5 contained molecules with $\mathrm{m} / \mathrm{z}$ ratios of $1072.6,1542.6,1031.4,1049.4,1081.5,1109.5,1485.7,1528.7$, 1123.5, 1086.6, 1499.7, and 1556.7 (Figure 5). There were two isomers of iturin $\mathrm{B}(\mathrm{m} / \mathrm{z}$ ratios 1072.6 and 1086.6), two isomers of fengycin $B(\mathrm{~m} / \mathrm{z}$ ratios 1542.6 and 1556.7$)$, one isomer of bacillomycin $\mathrm{D}$ ( $\mathrm{m} / \mathrm{z}$ ratio 1031.4$)$, one isomer of surfactin ( $\mathrm{m} / \mathrm{z}$ ratio 1049.4$)$, two isomers of iturin $\mathrm{A}(\mathrm{m} / \mathrm{z}$ ratios 1109.5 and 1123.5$)$, and three isomers of fengycin $(\mathrm{m} / \mathrm{z}$ ratios 1485.7 , 1499.7, and 1528.7). We also detected a set of $\mathrm{m} / \mathrm{z}$ ratios (with a corresponding mass difference of $22 \mathrm{Da}$ ) that we putatively ascribed to sodium adducts of bacillomycin $\mathrm{D}(\mathrm{m} / \mathrm{z}$ ratio 1081.5$)$ (He, 2002).
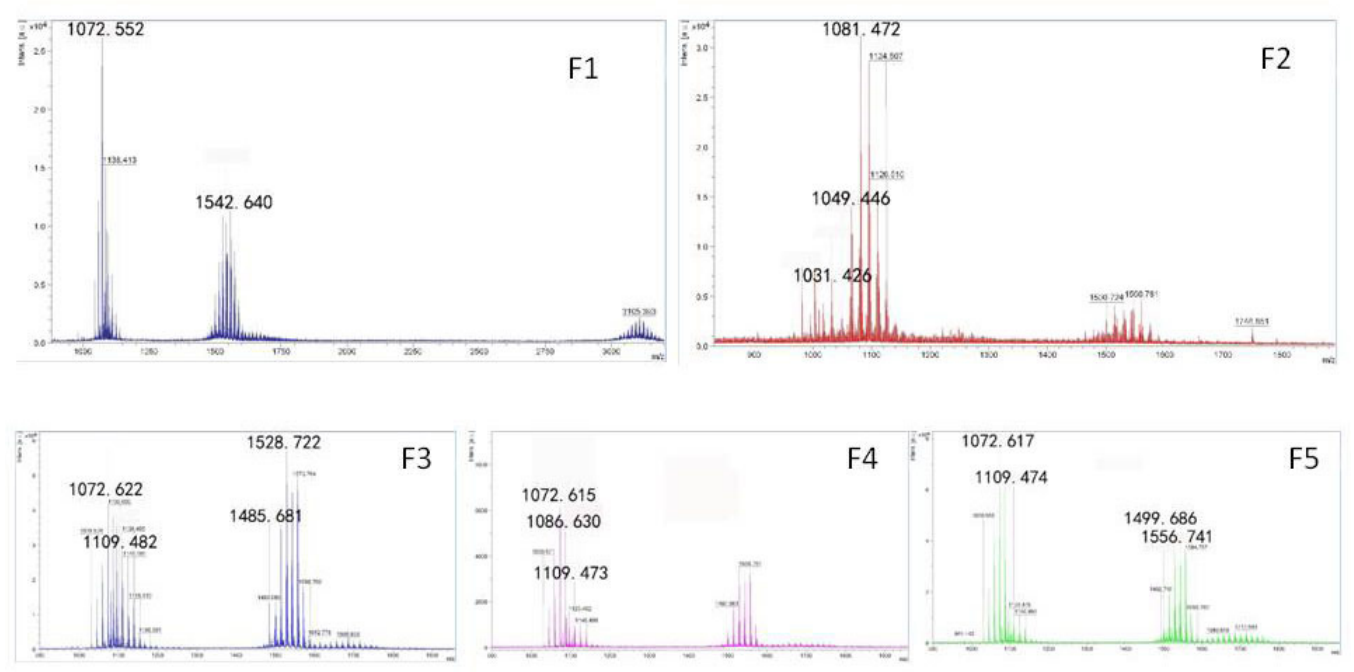

Figure 5. Matrix-assisted laser desorption ionization-time of flight (MALDI-TOF) mass spectra for the five samples: F1, F2, F3, F4, and F5.

\section{DISCUSSION}

Plant diseases must be controlled by applying biological preparations to reduce costs, address environmental concerns, and protect health. The efficacy of antagonistic organisms that protect plants from root rot disease has been evaluated. For instance, Chakraborty et al. (2009) reported that Ochrobactrum anthropi TRS-2 isolated from tea rhizospheres solubilized phosphates, produced siderophores and indole-3-acetic acid in vitro, and exhibited antifungal activity against six test pathogens. $O$. anthropi treatment also decreases the incidence of brown root rot caused by P. noxius in tea (Chakraborty et al., 2009). With regard to rubber root disease, Trichoderma isolates obtained from rubber-growing areas have antagonistic effects 
on Rigidoporus microporus, and Trichoderma harzianum can also control R. microporus in vitro (Jayasuriya and Thennakoon, 2007). The in vitro and in vivo control of fungal antagonists has been evaluated against $R$. lignosus in H. brasiliensis (Willd. ex A. Juss.) Muell. Arg. in a rainforest in Nigeria. The dual inoculations of the fungal antagonists and $R$. lignosus inoculated on the same day differed significantly from the antagonists inoculated $24 \mathrm{~h}$ before inoculation with $R$. lignosus. Among the biocontrol agents, Hypocrea jecorina is most effective for controlling $R$. lignosus, with a percentage inhibition of $86.83 \%$. Hypocrea virens, Hypocrea jecorina, Trichoderma spp including Trichoderma spirale and Trichoderma Pers, and Hypocrea lixii are also effective against R. lignosus (Ogbebor et al., 2015). In the first step of biocontrol, microbes from the environment, such as soil or plants, are isolated and identified; in the second step, pure cultures are examined to determine their antagonistic effects. In this study, we identified peptide-related genes using PCR and antibiotic substances using MALDI-TOF-MS. The B. subtilis Czk1 genes related to the synthesis of surfactins, iturins, and fengycins were amplified by PCR, and the signals generated by these substances were detected by MALDITOF-MS. We found that $B$. subtilis Czk1 produces lipopeptide antibiotics such as surfactins, iturins, and fengycins. Interesting results can be obtained using PCR and MALDI-TOF-MS. For example, $\mathrm{Li}$ (2009) found that the two methods produced different results when applied to the lipopeptides from $B$. subtilis $7 \mathrm{Ze} 3$; the genes related to surfactin synthesis were not detected by PCR amplification, but surfactins were detected by MALDI-TOF-MS. B. subtilis YB-05 has also been isolated from wheat rhizosphere soil, and the results of analysis revealed that this strain strongly inhibits the wheat take-all pathogen Gaeumannomyces graminis var. tritici. Seven primer pairs have also been evaluated to detect antifungal genes; four have been detected in B. subtilis YB-05 but the other three genes were not found. When B. subtilis YB05 was grown in liquid culture medium under specific conditions, six main types of antifungal substances were detected through analysis by mass spectrometry (Yang et al., 2015). The difference between the number of antifungal genes and the number of the expressed products in the culture supernatant can be attributed to the specific liquid culture growth conditions that may not have permitted the production of the final products of the hyphae (Yang et al., 2015). Therefore, PCR can provide the basis for follow-up to MALDI-TOF-MS analysis. However, false-positive results may be obtained for the identification of peptide-related genes if PCR alone is used. The accuracy of peptide-related gene detection is probably improved by primary identification through PCR and further detection through MALDI-TOF-MS, because the latter process is acutely sensitive and highly efficiency.

The number and type of antimicrobial peptide genes may vary in B. subtilis strains. Yang et al. (2015) found that B. subtilis YB05 contains at least four antifungal genes ( $f e n B$, $i t u A$, hag, and tas); the other antifungal genes tested (spaS, sfp, and mycB) may also be present but were not detectable using the primers and PCR conditions used in this study. The antimicrobial peptide (AMP) biosynthetic genes $\operatorname{srfAA}$ (surfactin), bacA (bacilysin), fenD (fengycin), bmy $B$ (bacillomycin), spaS (subtilisin), and $i t u C$ (iturin) have been examined in 184 Bacillus spp isolates obtained from plant environments, including aerial, rhizosphere, and soil environments in Spain (Mora et al., 2011). Most of the strains comprise two or four AMP genes; strains with five genes are rarely detected, and none of the strains contains six genes (Mora et al., 2011). By contrast, B. subtilis A1/3 shows exceptionally diverse antibiotic capacity; this strain also comprises six AMP genes, namely, srf (surfactin), bacA, fenD, $b m y B$, spaS, and ituC (iturin) (Hofemeister et al., 2004). In our study, four primer pairs were designed to detect antifungal genes in B. subtilis Czk1. The results showed that four specific

Genetics and Molecular Research 16 (1): gmr16018710 
PCR primers, which targeted the flanking region of the gene-coding regions, amplified the predicted fragments from the genomic DNA of $B$. subtilis Czk1. This finding indicates that $B$. subtilis Czk1 carries $s f p, f e n B$, ituD, and lpa.

Bacterial strains produce various antimicrobial biosurfactants such as the lipopeptide antibiotics classified as iturins or surfactins (Chen and Hoover, 2003). SK.DU.4, a novel strain identified during the screening of soil bacteria for antimicrobial substance production, produces bacteriocin-like peptide and lipopeptide (Baindara et al., 2013). Three kinds of antibiotics have also been isolated from B. subtilis JA, and include the lipopeptide family surfactin, iturin, and fengycin (Chen et al., 2008). However, the co-production of lipopeptides causes purification problems (Akpa et al., 2001). In our study, four main types of antifungal substances were detected by MALDI-TOF-MS after liquid culture of strain Czk1 under specific conditions: isomers of iturin (iturin A, iturin A1, iturin B, and iturin B1), fengycin (fengycin, fengycin1, fengycin2, fengycinB1, and fengycin B2), bacillomycin (bacillomycin D1 and bacillomycin D2), and surfactin. Surfactin, fengycin, and iturin were produced by B. subtilis Czk1, and five active fractions were separated. The active fractions were mainly associated with F3; the other fractions had an inhibitory effect on the plate and inhibited $C$. gloeosporioides conidium germination to some extent; at high concentrations, the top of the conidium expanded and became malformed. Therefore, the type and content of bacteriostatic substances should be investigated further because the five fractions detected by MALDI-TOFMS comprise more than one component. Further investigations are underway to promote $B$. subtilis Czk1 in agricultural applications.

\section{Conflicts of interest}

The authors declare no conflict of interest.

\section{ACKNOWLEDGMENTS}

Research supported by a research grant from the National Natural Rubber Industry Technology System (\#CARS-34-GW8), and by fundamental research funds from the Environment and Plant Protection Institute at the Chinese Academy of Tropical Agricultural Sciences (\#2014hzs1J013).

\section{REFERENCES}

Akpa E, Jacques P, Wathelet B, Paquot M, et al. (2001). Influence of culture conditions on lipopeptide production by Bacillus subtilis. Appl. Biochem. Biotechnol. 91-93: 551-561. http://dx.doi.org/10.1385/ABAB:91-93:1-9:551

Arima K, Kakinuma A and Tamura G (1968). Surfactin, a crystalline peptidelipid surfactant produced by Bacillus subtilis: isolation, characterization and its inhibition of fibrin clot formation. Biochem. Biophys. Res. Commun. 31: 488-494. http://dx.doi.org/10.1016/0006-291X(68)90503-2

Baindara P, Mandal SM, Chawla N, Singh PK, et al. (2013). Characterization of two antimicrobial peptides produced by a halotolerant Bacillus subtilis strain SK.DU.4 isolated from a rhizosphere soil sample. AMB Express 3: 2 http://dx.doi. org/10.1186/2191-0855-3-2.

Cai Z, Li G, Lin C, Shi T, et al. (2013). Identifying pathogenicity genes in the rubber tree anthracnose fungus Colletotrichum gloeosporioides through random insertional mutagenesis. Microbiol. Res. 168: 340-350. http://dx.doi.org/10.1016/j. micres.2013.01.005

Cai ZY, Li JZ, He MX, Xiao CY, et al. (2009). The effect of three hot fogging concentrates on Colletotrichum leaf fall of rubber tree in rubber plantation. Trop. Agr. Sci. Technol. 32: 10-11.

Genetics and Molecular Research 16 (1): gmr16018710 
Chakraborty U, Chakraborty BN, Basnet M and Chakraborty AP (2009). Evaluation of Ochrobactrum anthropi TRS-2 and its talc based formulation for enhancement of growth of tea plants and management of brown root rot disease. $J$. Appl. Microbiol. 107: 625-634. http://dx.doi.org/10.1111/j.1365-2672.2009.04242.x

Chee KH (1990). Present status of rubber diseases and their control. Review of Plant Pathol. 69: 423-430.

Chen H and Hoover DG (2003). Bacteriocins and their food applications. Comp. Reviews in Food Sci. Food Saf. 2: 82-100.

Chen H, Wang L, Su CX, Gong GH, et al. (2008). Isolation and characterization of lipopeptide antibiotics produced by Bacillus subtilis. Lett. Appl. Microbiol. 47: 180-186. http://dx.doi.org/10.1111/j.1472-765X.2008.02412.x

Delcambe L, Peypoux F, Besson F, Guinand M, et al. (1977). Structure of iturin and iturin-like substances [proceedings]. Biochem. Soc. Trans. 5: 1122-1124. http://dx.doi.org/10.1042/bst0051122

Dornelas MC and Rodriguez AP (2005). The rubber tree (Hevea brasiliensis Muell. Arg.) homologue of the LEAFY/ FLORICAULA gene is preferentially expressed in both male and female floral meristems. J. Exp. Bot. 56: 19651974. http://dx.doi.org/10.1093/jxb/eri194

Fan LY, He CP, Liang YQ, Zheng XL, et al. (2013). Characteristics of the antimicrobial active component of Bacillus subtilis strain Czk1. J. Trop. Biol. 4: 36-44.

Geetha I, Manonmani AM and Paily KP (2010). Identification and characterization of a mosquito pupicidal metabolite of a Bacillus subtilis subsp. subtilis strain. Appl. Microbiol. Biotechnol. 86: 1737-1744. http://dx.doi.org/10.1007/ s00253-010-2449-y

Gong M, Wang JD, Zhang J, Yang H, et al. (2006). Study of the antifungal ability of Bacillus subtilis strain PY-1 in vitro and identification of its antifungal substance (iturin A). Acta Biochim. Biophys. Sin. (Shanghai) 38: 233-240. http:// dx.doi.org/10.1111/j.1745-7270.2006.00157.x

He CP, Zhao LL, Shun L, Li R, et al. (2012). Identification and drug resistant analysis of a strain of siderophores producting antagonist bacteria from rubber tree. Redai Zuowu Xuebao 33: 2240-2245.

He MY (2002). Modern organic and biological mass spectrometry. Peking University Press, Beijing.

Hofemeister J, Conrad B, Adler B, Hofemeister B, et al. (2004). Genetic analysis of the biosynthesis of non-ribosomal peptide- and polyketide-like antibiotics, iron uptake and biofilm formation by Bacillus subtilis A1/3. Mol. Genet. Genomics 272: 363-378. http://dx.doi.org/10.1007/s00438-004-1056-y

Hou HM, Jin Y, Jin MF, Yu XY, et al. (2006). Structure, function and biosynthesis of cyclic lipopeptidic biosurfactants. Microbiology 33: 122-128.

Howarth FG (1991). Environmental impacts of classical biological control. Annu. Rev. Entomol. 36: 485-509. http:// dx.doi.org/10.1146/annurev.en.36.010191.002413

Hue N, Serani L and Laprévote O (2001). Structural investigation of cyclic peptidolipids from Bacillus subtilis by highenergy tandem mass spectrometry. Rapid Commun. Mass Spectrom. 15: 203-209. http://dx.doi.org/10.1002/10970231(20010215)15:3<203::AID-RCM212>3.0.CO;2-6

Jayasinghe CK, Fernando TH and Priyanka UM (1997). Colletotrichum acutatum is the main cause of Colletotrichum leaf disease of rubber in Sri Lanka. Mycopathologia 137: 53-56. http://dx.doi.org/10.1023/A:1006850119146

Jayasuriya KE and Thennakoon BI (2007). Biological control of Rigidoporus microporus, the cause of white root disease in rubber. Cey. J. Sci. 36: 9-16.

Klaenhammer TR (1993). Genetics of bacteriocins produced by lactic acid bacteria. FEMS Microbiol. Rev. 12: 39-85. http://dx.doi.org/10.1111/j.1574-6976.1993.tb00012.x

Koumoutsi A, Chen XH, Henne A, Liesegang H, et al. (2004). Structural and functional characterization of gene clusters directing nonribosomal synthesis of bioactive cyclic lipopeptides in Bacillus amyloliquefaciens strain FZB42. J. Bacteriol. 186: 1084-1096. http://dx.doi.org/10.1128/JB.186.4.1084-1096.2004

Kowall M, Vater J, Kluge B, Stein T, et al. (1998). Separation and characterization of surfactin isoforms produced by Bacillus subtilis OKB 105. J. Colloid Interface Sci. 204: 1-8. http://dx.doi.org/10.1006/jcis.1998.5558

Li HF (2009). Study on secondary metabolites of Bacillus subtilis 7Ze3. Masters degree thesis, Nanjing Agriculture University, Nanjing, China.

Limkaisang S, Kom-un S, Fertado EL, Liew KW, et al. (2005). Molecular phylogenetic and morphological analysis of Oidium heveae, a powdery mildew of rubber tree. Mycoscience 46: 220-226. http://dx.doi.org/10.1007/S10267-005-0238-8

Mahoney MJ and Tattar TA (1980). Identification, etiology, and control of Euonymus fortunei anthracnose caused by Colletotrichum gloeosporioides. Plant Dis. 64: 854-856. http://dx.doi.org/10.1094/PD-64-854

Mitra M and Mehta PR (1938). Some leaf diseases of Hevea brasiliensis new to India. Indian J. Agric. Sci. 8: 185-188.

Mora I, Cabrefiga J and Montesinos E (2011). Antimicrobial peptide genes in Bacillus strains from plant environments. Int. Microbiol. 14: 213-223.

Mukherjee S, Das P and Sen R (2006). Towards commercial production of microbial surfactants. Trends Biotechnol. 24: 509-515. http://dx.doi.org/10.1016/j.tibtech.2006.09.005

Genetics and Molecular Research 16 (1): gmr16018710 
Nagórska K, Bikowski M and Obuchowski M (2007). Multicellular behaviour and production of a wide variety of toxic substances support usage of Bacillus subtilis as a powerful biocontrol agent. Acta Biochim. Pol. 54: 495-508.

Ogbebor NO, Adekunle AT, Eghafona ON and Ogboghodo AI (2015). Biological control of Rigidoporus lignosus in Hevea brasiliensis in Nigeria. Fungal Biol. 119: 1-6. http://dx.doi.org/10.1016/j.funbio.2014.10.002

Oghenekaro AO, Miettinen O, Omorusi VI, Evueh GA, et al. (2014). Molecular phylogeny of Rigidoporus microporus isolates associated with white rot disease of rubber trees (Hevea brasiliensis). Fungal Biol. 118: 495-506. http:// dx.doi.org/10.1016/j.funbio.2014.04.001

Pathak KV and Keharia H (2014). Identification of surfactins and iturins produced by potent fungal antagonist, Bacillus subtilis K1 isolated from aerial roots of banyan (Ficus benghalensis) tree using mass spectrometry. 3 Biotech. 4: 283-295.

Pathak KV, Keharia H, Gupta K, Thakur SS, et al. (2012). Lipopeptides from the banyan endophyte, Bacillus subtilis K1: mass spectrometric characterization of a library of fengycins. J. Am. Soc. Mass Spectrom. 23: 1716-1728. http:// dx.doi.org/10.1007/s13361-012-0437-4

Pecci Y, Rivardo F, Martinotti MG and Allegrone G (2010). LC/ESI-MS/MS characterisation of lipopeptide biosurfactants produced by the Bacillus licheniformis V9T14 strain. J. Mass Spectrom. 45: 772-778. http://dx.doi.org/10.1002/ jms. 1767

Peres NAR, Souza NL, Peever TL and Timmer LW (2004). Benomyl sensitivity of isolates of Colletotrichum acutatum and C. gloeosporioides from citrus. Plant Dis. 88: 125-130. http://dx.doi.org/10.1094/PDIS.2004.88.2.125

Peypoux F, Bonmatin JM, Labbe H, Grangemard I, et al. (1994). [Ala4]surfactin, a novel isoform from Bacillus subtilis studied by mass and NMR spectroscopies. Eur. J. Biochem. 224: 89-96. http://dx.doi.org/10.1111/j.1432-1033.1994. tb19998.x

Rodrigues L, Banat IM, Teixeira J and Oliveira R (2006). Biosurfactants: potential applications in medicine. J. Antimicrob. Chemother. 57: 609-618. http://dx.doi.org/10.1093/jac/dk1024

Romero D, de Vicente A, Rakotoaly RH, Dufour SE, et al. (2007). The iturin and fengycin families of lipopeptides are key factors in antagonism of Bacillus subtilis toward Podosphaera fusca. Mol. Plant Microbe Interact. 20: 430-440. http://dx.doi.org/10.1094/MPMI-20-4-0430

Stein T (2005). Bacillus subtilis antibiotics: structures, syntheses and specific functions. Mol. Microbiol. 56: 845-857. http://dx.doi.org/10.1111/j.1365-2958.2005.04587.x

Steller S, Vollenbroich D, Leenders F, Stein T, et al. (1999). Structural and functional organization of the fengycin synthetase multienzyme system from Bacillus subtilis b213 and A1/3. Chem. Biol. 6: 31-41. http://dx.doi.org/10.1016/ $\underline{\text { S1074-5521(99)80018-0 }}$

Thambugala TADP and Deshappriya N (2009). The role of Colletotrichum species on the Colletotrichum leaf disease of Hevea brasiliensis: a preliminary study. J. Natl. Sci. Found. Sri Lanka 37: 135-138.

Vanittanakom N, Loeffler W, Koch U and Jung G (1986). Fengycin--a novel antifungal lipopeptide antibiotic produced by Bacillus subtilis F-29-3. J. Antibiot. 39: 888-901. http://dx.doi.org/10.7164/antibiotics.39.888

Vater J, Kablitz B, Wilde C, Franke P, et al. (2002). Matrix-assisted laser desorption ionization--time of flight mass spectrometry of lipopeptide biosurfactants in whole cells and culture filtrates of Bacillus subtilis C-1 isolated from petroleum sludge. Appl. Environ. Microbiol. 68: 6210-6219. http://dx.doi.org/10.1128/AEM.68.12.6210-6219.2002

Wastie RL (1967). Gloeosporium leaf disease of rubber in West Malaysia. Planter, Kuala Lumpur 43: 553-565.

Williams SM and Brodbelt JS (2004). MS(n) characterization of protonated cyclic peptides and metal complexes. J. Am. Soc. Mass Spectrom. 15: 1039-1054. http://dx.doi.org/10.1016/j.jasms.2004.03.015

Winkelmann G, Allgaier H, Lupp R and Jung G (1983). Iturin AL--a new long chain iturin a possessing an unusual high content of C16-beta-amino acids. J. Antibiot. 36: 1451-1457. http://dx.doi.org/10.7164/antibiotics.36.1451

Yang LR, Quan X, Xue BG, Goodwin PH, et al. (2015). Isolation and identification of Bacillus subtilis strain YB-05 and its antifungal substances showing antagonism against Gaeumannomyces graminis var. tritici. Biol. Control 85: 5258. http://dx.doi.org/10.1016/j.biocontrol.2014.12.010

Yong HY, Bakar FD, Illias RM, Mahadi NM, et al. (2014). Cgl-SLT2 is required for appressorium formation, sporulation and pathogenicity in Colletotrichum gloeosporioides. Braz. J. Microbiol. 44: 1241-1250. http://dx.doi.org/10.1590/ $\underline{\mathrm{S} 1517-83822013000400031}$

Zhao LL, He CP, Zheng XL, Fan LY, et al. (2011). Effect of Bacillus subtilis strain Czk1 on different rubber root pathogens and in vitro control of Colletotrichum gloeosporioides on rubber leaf. J. Southern Agr. 42: 740-743.

Genetics and Molecular Research 16 (1): gmr16018710 